\title{
Performance Test of Parabolic Type Equilibrium Shoreline Formula Using Wave Data Observed in East Sea
}

\author{
Chang Bin Lim $\circledast^{*}$ and Jung Lyul Lee ${ }^{* *}$ \\ "School of Civil, Architecture and Environmental System Engineering, Sungkyunkwan University, Suwon, Korea \\ ${ }^{*}$ School of Water Resources Engineering, Sungkyunkwan University, Suwon, Korea \\ 동해 파랑관측 자료를 활용한 포물선형 평형해안선 식의 타당성 조사 \\ 임창빈 $\odot^{*}$ 이정렬** \\ "성균관대학교 건설환경시스템공학부 \\ *성균관대학교 수자원대학원
}

KEY WORDS: East Coast 동해안, Groyne 돌제, Wave directional spectrum 파향스펙트럼, Wave rose 파랑장미도, Littoral drift rose 연 안표사장미도, Shoreline gradient 해안선 기울기

\begin{abstract}
The present study investigated the validity of an equilibrium shoreline empirical formula for real phenomena. Among three types of equilibrium shoreline formulas, Hsu's parabolic type static formula was employed, which is well-known and the most practical for shoreline estimation after coastal or harbor structure construction. The wave data observed at Maengbang beach and the CERC formula on longshore sediment transport were used in the present investigation. A comparison study was only conducted for the case of a shoreline change after the construction of a groyne. Reasonable agreement was seen between the observed wave data and the data obtained under a wave angle spreading function $S=3.5$. However, significant changes were observed when $S$ increased. Thus, careful application is required when using Hsu's formula
\end{abstract}

\section{1. 서 론}

오늘날 전 세계적으로 해안에는 항만구조물 뿐만 아니라 다 양한 해안구조물 등 많은 인공 구조물들이 파랑의 제어나 표사 의 제어를 위하여 해안가에 설치되고 있다. 항만 구조물이 들어 서는 경우 주변 해역의 파랑장의 변화가 발생하여 궁극적으로 해안선의 변화가 초래된다. 우리나라의 경우 연안침식 문제를 유발한 사례는 매우 많은 실정이다. 대표적인 사례만 들면 강원 도 속초시의 속초항, 강릉시의 강릉항, 삼척시의 궁촌항과 $\mathrm{LNG}$ (Liquefied natural gas)기지, 경북 포항시의 포항신항, 전북 고창 군 구시포항, 제주도 서귀포시의 성산항 등의 항만 구조물이 그 런 예이다. 그러나 그 변화를 예측하는 데 있어서 아직도 기술 적으로 많은 불확실성이 존재한다.

특히 침식 문제를 해결하기 위하여 연안 해역에 배치되는 해 안구조물이 오히려 더 심각한 침식문제를 야기하기도 하는 국 내 사례는 해안공학의 국내 기술 수준이 아직도 선진국 수준에 도달하지 못하였다는 것을 반증한다. 대표적인 사례는 강원 속
초시의 영랑해변의 헤드랜드 공법의 배치 부실설계이다. 심지 어 이런 실패 사례가 있었음에도 비슷한 형태의 항만구조물을 설치하여 유사한 침식 사례를 낳게 하고 있는 경북 울진군 봉 평해안의 헤드랜드 공법의 사례이다. 최근 Kang et al.(2010)은 강원 속초시 영랑해변의 침식 사례를 활용하여 해빈침식대책으 로 건설된 인공구조물 축조 후 해안선 침식 현상을 정성적으로 관찰하였다. 그리고 이를 통해 올바르지 않은 해안구조물의 건 설은 오히려 더 심한 침식피해를 일으킬 수 있음을 증명하였다. 또한 잠제의 본래의 기능은 고파랑 제어와 이에 의한 침식 폭 저감임에도 연안표사 제어가 필요한 침식 해변에서도 무분별하 게 남용하는 일련의 사례는 국내 연안 침식문제 해결에 있어 아직도 해안구조물의 배치설계 수준이 전문성을 갖추지 못한 민낮을 드러내고 있음을 반증한다.

최근 이러한 항만 및 해안 구조물의 설치에 따른 해안선의 새 로운 변화를 예측하기 위한 실제 지형과의 맞춤에 의한 모방 연구, 현장 조건을 비슷하게 재현하는 수리모형 실험 연구, 그 리고 모의 계산 기술을 활용한 수치모형 개발 연구 등이 활발

Received 22 March 2018, revised 21 April 2018, accepted 23 April 2018

Corresponding author Jung-Lyul Lee: +82-31-290-7519, jllee@skku.edu ORCID: https://orcid.org/0000-0001-9410-9725

(C) 2018, The Korean Society of Ocean Engineers

This is an open access article distributed under the terms of the creative commons attribution non-commercial license (http://creativecommons.org/licenses/by-nc/3.0) which permits unrestricted non-commercial use, distribution, and reproduction in any medium, provided the original work is properly cited. 
히 이루어지고 있다. 표사이동 메커니즘에 기반을 두게 된 수치 모형은 단기적인 침퇴적율의 예측에는 제한적인 신뢰성을 갖추 고 적용되고 있다. 그러나 아직 해저면 변화가 동반된 1 2년 이 상의 장기적인 예측에는 적용되지 못하거나 신뢰도가 낮은 수 준이다. 따라서 해안구조물의 설치에 따른 해안선 예측 등은 아 직도 모방 연구 결과에 크게 의존할 수밖에 없는 실정이다. 최 근 Lee and $\mathrm{Hsu}(2017)$ 는 연안표사량 식과 고파랑에 대한 해안선 의 반응 관계를 결합하여 장기적인 연안표사는 물론 단기적인 횡단 표사를 결합한 모형을 개발하였다. 특히 $\mathrm{Hsu}$ 의 평형해안 선으로 수렴하도록 하여 불확실성이 많은 장기적인 변화임에도 모의 연구 결과를 반영하여 실용적이면서도 사전 검토 수단으 로서 유용한 해안선변형모형을 개발하였다.

평형해안선에 대한 경험식 제시가 대표적인 모방 연구 결과 물로서 다음과 같이 3 가지 종류가 종종 인용된다. 즉, 로그 나 선형(Log spiral; Yasso, 1965), 포물선 형(Parabolic shape; Hsu et al., 1987), 그리고 쌍곡선 탄젠트 형 (Hyperbolic tangent shape; Moreno and Kraus 1999)등이 있다. 특히 Hsu et al.(1987)의 평형 해안선 경험식은 Suh and Dalrymple(1987)의 수리 실험 결과와 유사한 결과를 제시하는 경험식이다. 그리고 대부분의 인공구 조물 축조 후의 해안선 변형 문제에 있어서 사전에 해안선 변 형을 검토하는 데 상당히 유용한 검토 수단으로서 충분한 신뢰 성을 확보한 것으로 판단하고 있다(Lee and $\mathrm{Hsu}, 2017)$.

Hsu et al.,(1987)의 평형해안선 경험식은 우리나라 해안선 변 화 예측에도 만족할 만한 결과를 도출하고 있는 것으로 판단하 고 있는 상태이다. 하지만 아직 그 효용성에 비하여 연안정비사 업 등의 침식 저감시설로서의 해안구조물의 배치 설계에 도입 되지 못하고 있는 실정이다. Gonzalez et al.,(2010)은 Hsu et al.,(1987)의 평형해안선 경험식을 실제 스페인 Poniente 해변에 적용시켜 장기적인 해안선 변화와 매우 유사한 실험 결과를 도 출함을 통해 타당성을 입증하였다. 그리고 이를 활용하여 양빈 계획을 수립하거나 해안구조물 건설 이후에 해안선 변화를 예 측하는 수단으로 활용하게 될 것이다.

$\mathrm{Hsu}$ 의 평형 해안선 경험식은 이와 같이 특별한 모니터링 자 료가 없이도 인공 해안구조물의 축조 후에 해안선 변화를 추정 하는데 있어 독보적인 수단인 것으로 평가받는다. 본 연구에서 는 $\mathrm{Hsu}$ 의 평형 해안선 경험식이 파랑 관측 자료와 연안표사량 공식을 통하여 얼마나 타당한지를 평가한다. 또한 파향스펙트 럼의 분포 특성에 따라서 평형 해안선이 어떻게 반응하는 지를 살펴본다.

\section{Hsu의 평형해안선}

\subsection{Hsu의 평형해안선 경험식}

$\mathrm{Hsu}$ et al.,(1987)이 제시한 포물선형의 평형 해안형상 경험식 은 다음 식 (1)-(2)와 같이 주어진다.

$$
\begin{aligned}
& R(\theta)=\frac{a}{\sin \beta}\left[C_{0}+C_{1}\left(\frac{\beta}{\theta}\right)+C_{2}\left(\frac{\beta}{\theta}\right)^{2}\right] \text { for } \theta \geq \beta \\
& R(\theta)=\frac{a}{\sin \theta} \text { for } \theta \leq \beta
\end{aligned}
$$

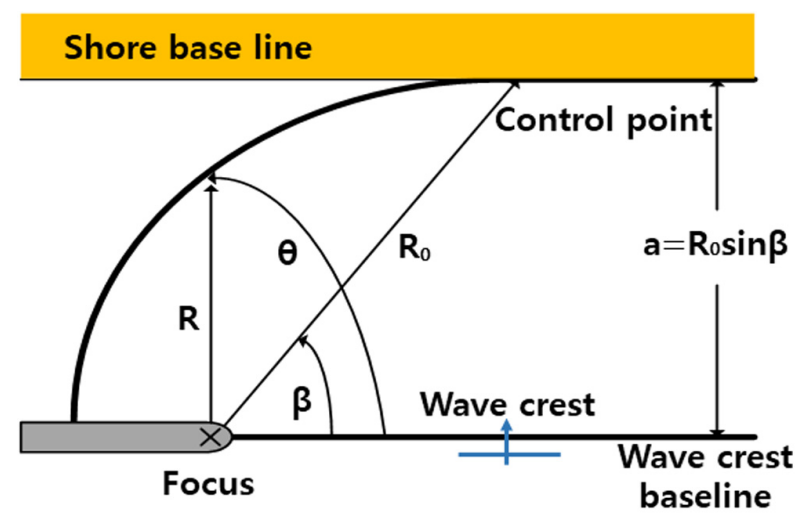

Fig. 1 Definition sketch of Hsu's formula

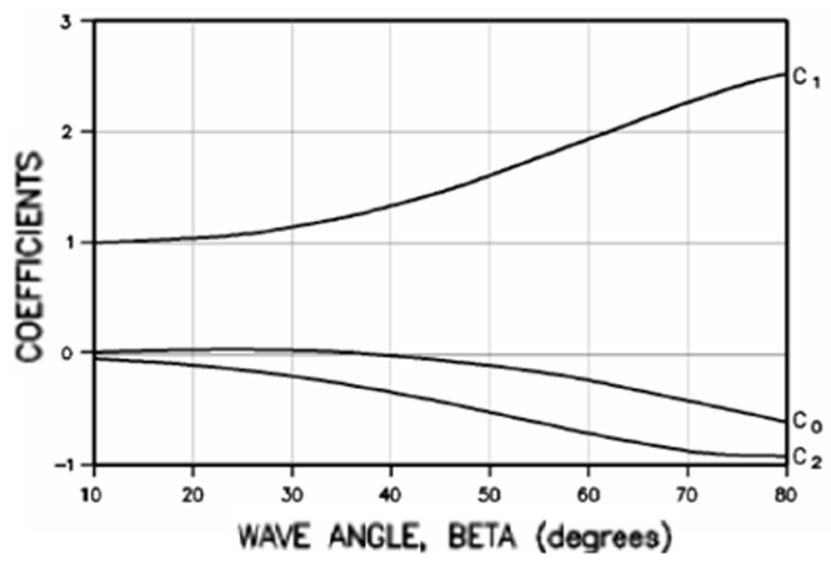

Fig. 2 Coefficients of Hsu's formula (Hsu et al., 1987)

여기서, $R$ 은 포물선 초점(Parabolic focus)로부터 해안선까지의 거리, $a$ 는 초점을 지나는 주파향 파봉선(파봉기준선)과 이와 평 행하게 평형기준점(Control point)을 지나는 선(해안기준선)과의 이격 거리, $\beta$ 는 파봉기준선과 초점으로부터 평형기준점을 지나 는 선이 이루어지는 각도, $\theta$ 는 파봉기준선과 초점으로부터 평 형해안선을 연결한 선이 이루는 각도, 그리고 $C_{0}$ 와 $C_{1}, C_{2}$ 는 Fitting 계수이며, Appendix Table A1에 제시된 바와 같이 $\mathrm{Hsu}$ and Evans(1989)에 의해 제공되었다. $\theta \geq \beta$ 인 Bay구간과 $\theta \leq \beta$ 인 직선구간이 서로 연결되기 위해서는 계수 3 개의 총합이 1 이 되 어야 한다.

백사장이 길게 발달하여 영향점이 초점에서 멀리 떨어진 경우에 는 간단한 근사치를 얻을 수 있다. 이 경우에는 $\beta$ 의 값이 0 에 가까워 지면서, $\sin \beta$ 가 $\beta$ 에 수렴하고, $C_{0}$ 와 $C_{2}$ 항은 무시할 수 있으며, $C_{1}$ 은 1 에 수렴한다. 그러므로 식(1)에 대한 간단한 근사치는 식 (3)와 같은 간단한 관계식 $R(\theta)$ 로 표현된다.

$$
R(\theta)=\frac{\beta}{\sin \beta} \frac{a}{\theta}
$$

이 경우에는 초점을 지나는 주파향 파봉선과 평형기준점을 지나 는 선과의 이격거리 $a$ 와 파봉기준선과 초점으로부터 평형해안선 을 연결한 선이 이루는 각도 $\theta$ 만 알게 된다면 평형해안선을 추정할 수 있게 된다. 


\section{2 동해의 $\mathrm{Hsu}$ 의 평형해안선의 회전각 산정}

위와 같은 $\mathrm{Hsu}$ et al.(1987)의 평형해안선 경험식으로부터 동 해안의 평형해안선을 추정할 수 있다. $\mathrm{Hsu}$ 의 평형해안선 경험 식 (1)으로부터 $\theta$ 방향에 대한 평형해안선의 회전 각도를 구하면 아래의 식 (4)과 같다.

$$
\frac{\partial R}{R \partial \theta}=S=-\frac{1}{R} \frac{a}{\theta \sin \beta}\left[C_{1} \frac{\beta}{\theta}+2 C_{2}\left(\frac{\beta}{\theta}\right)^{2}\right]
$$

또한 식 (2)의 경우와 같이 만약 $\beta$ 가 0에 가까워서 연안표사 의 상류 경계인 Control point가 무한한 위치에 놓여 있다면 식 (4)에서 $C_{2}$ 가 0으로 취급되어 아래 식 (5)와 같이 간단한 형태의 수식이 된다.

$$
\frac{\partial R}{R \partial \theta}=S=-\frac{\beta}{R \sin \beta} \frac{a}{\theta^{2}}
$$

그리고 Fig. 3에 도시된 바와 같이 기존 해안에 대한 회전각 도 $\phi$ 로 변환하기 위하여 아래 과정이 추가된다.

$$
\phi=\theta+\psi-\frac{\pi}{2}=\theta+\tan ^{-1}(S)-\frac{\pi}{2}
$$

이와 같은 과정을 통하여 $\mathrm{Hsu}$ 의 평형해안선 경험식으로부터 포물선형 평형해안선의 회전각을 구할 수 있다.

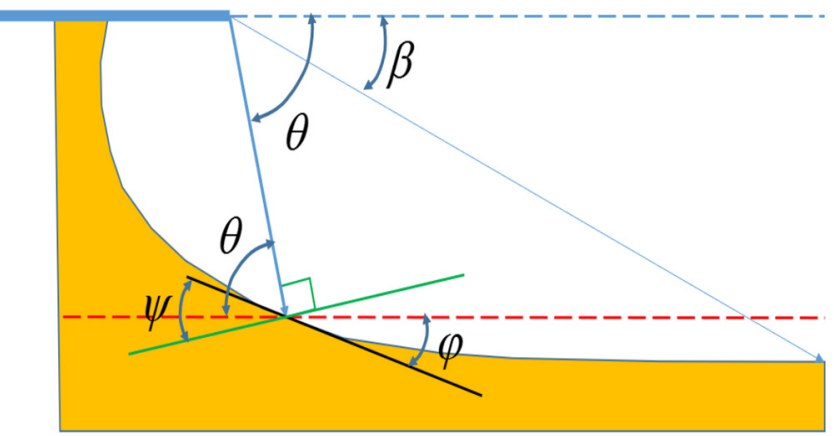

Fig. 3 Definition sketch of equilibrium shoreline gradient $\phi$

\section{3. 동해의 방파제 건설 후 해안선 변화 추정}

\section{1 연안표사공식}

연안 표사는 입사 파랑이 해안선에 빗각으로 유입되는 경우에 파랑의 작용으로 연안을 따라 이동한다. 전체 해빈단면을 따라 적분된 전연안표사 이동량 $\mathrm{Q}($ Total longshore sediment transport rate)는 아래 식 (7)과 같이 쇄파지점에서의 파력의 크기, 해안선과 파봉선간의 사이각, 표사의 단위중량 등에 따라 산정되며 미공병 단에 의하여 제안된 식으로 $\mathrm{CERC(Coastal} \mathrm{Engineering} \mathrm{Research}$ Center)식이라고도 한다.

$$
Q_{y}=\frac{I_{y}}{\left(\rho_{s}-\rho\right)(1-p) g}
$$

여기서 $\rho$ 는 해수의 비중이고 $\rho_{s}$ 는 모래 입자의 비중, $p$ 는 0.3 0.4 의 값을 갖는 토사 공극율(Sediment porosity), $g$ 는 중력가속 도이다. 그리고

$$
I_{y}=K\left(E C_{g}\right)_{b} \cos \alpha_{b} \sin \alpha_{b}=\frac{K}{16} \rho g H_{b}^{2} \sqrt{g h_{b}} \sin 2 \alpha_{b}
$$

여기서 $E C_{g}$ 는 Wave energy flux이며, $H_{b}$ 는 쇄파고, $h_{b}$ 는 쇄파 수심, $\alpha_{b}$ 는 쇄파점에서 해안선과 파봉선간의 사이각, $K$ 는 상수 로서 표사량 조건에 따라 대개 작게는 0.04 로부터 크게는 1.1 까 지 다양한 값을 가질 수 있지만 보통 0.77로 간주된다. 식 (8)에 서 $H_{b}=\Upsilon h$ 로 두고 표사의 단위 중량, 공극율 등 파랑 조건과 관련되지 않은 것을 상수 $C$ 으로 두고 정리하면 다음과 같이 쇄파고 $H_{b}$ 와 쇄파입사각 $\alpha_{b}$ 의 함수로 주어지는 연안 표사량 (Longshore sediment transport rate) $Q_{y}$ 을 얻을 수 있다.

$$
Q_{y}=C^{\prime} H_{b}^{5 / 2} \sin 2 \alpha_{b}
$$

여기서 $C^{\prime}=\frac{K \sqrt{g / \kappa}}{16(s-1)(1-p)}$ 이며 대부분의 모래에 대해 약 0.167 의 값을 갖는다. 여기서 $K=0.77, g=9.81 \mathrm{~m} / \mathrm{s}^{2}$, 그리고 대부분의 해사에 적용되는 $s=2.57, p=0.35$ 가 적용되었다.

심해 파랑 자료로부터 연안 표사량을 직접 추정하는 것은 상 당히 유용하다. 해안의 등수심선이 직선적이고 해안선에 모두 평행하다면 아래와 같이 심해 파 정보로 표현된다.

$$
Q_{y}=C_{o}^{\prime} H_{o}^{2.4} T_{o}^{0.2} \cos \alpha_{o}^{1.2} \sin \alpha_{o}
$$

여기서 $C_{o}^{\prime}=\frac{K^{0.6}}{16(s-1)(1-p)(2 \pi)^{0.2} \kappa^{0.4}}$ 이며 대부분의 모래에 대 해 약 0.142 의 값을 갖는다. 일반적으로 주기가 표사량에 미치 는 영향은 무시할 만하다.

해안선 방향에 따라 심해 입사 파향이 달라지므로 Fig. 4에서 정의된 바와 같이 진북으로부터의 해안선의 경사각 $\chi$ 를 고려하 면 식 (10)의 단위시간당 표사량은 다음과 같이 된다. 해안선의 방향 $\chi$ 는 Fig. 4 에서 도시된 것과 같이 해안선이 진북 $(\mathrm{N})$ 을 향 하면 $\chi=0^{\circ}$ 가 되며 동편에 바다가 존재하게끔 방향 설정을 하였 다. 따라서 해안선이 $\chi=180^{\circ}$ 에 대하여 해안선은 진남 $(\mathrm{S})$ 를 향 하고 바다는 서편에 위치하게 된다.

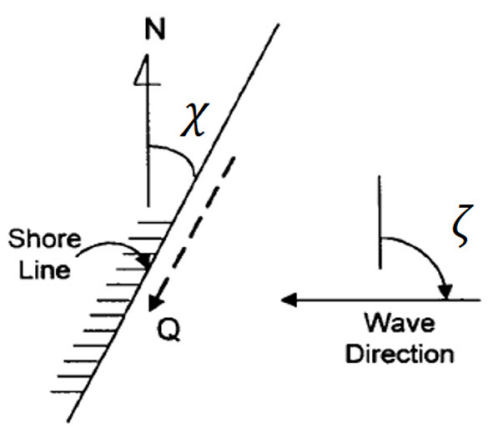

Fig. 4 Definition of the inclination angle of the shoreline from the true north $(\mathrm{N})$ and the wave direction angle of incidence wave 
Fig. 4 와 같이 정북 $\mathrm{N}$ 으로부터 정의된 해안선 방향 $\chi$, 입사 파향 $\xi$ 에 따라 식 (11)의 단위시간당 표사량은 다음과 같이 변환된다.

$$
Q_{y}=\frac{K g^{0.6} H_{o}^{2.4} T_{o}^{0.2} \cos \zeta^{1.2} \sin \zeta}{16(s-1)(1-p)(4 \pi)^{0.2} \kappa^{0.4}}
$$

여기서 $\zeta=\xi-\chi-\pi / 2$ 이고 표사량의 양수 $(+)$ 는 북쪽을 향하고 음 수(-)는 남쪽을 향한다. 또한 식 (10)과 같이 상수를 도입하여 표 현하면 아래와 같이 입사파랑 조건으로 표현된다.

$$
Q_{y}=C_{o}^{\prime} H_{o}^{2.4} T_{o}^{0.2} \cos \zeta^{1.2} \sin \zeta
$$

\section{2 입사파랑의 특성 분석}

2013년 9월 27일부터 10시 30분부터 2016년 11월 21일 9시 30분까 지 삼척시 맹방 해변 전면 (위도: $37^{\circ} 24^{\prime} 00.0^{\prime \prime} \mathrm{N}$, 경도 $129^{\circ} 14^{\prime} 05$. $\left.2^{\prime \prime} \mathrm{E}\right)$ 의 수심 $32.4 \mathrm{~m}$ 에서 관측되어 30 분 간격으로 산출된 총

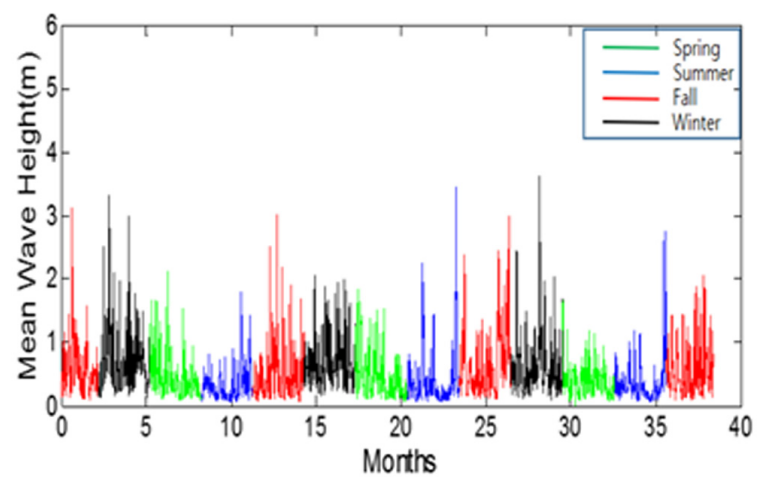

Fig. 6 Temporal variation of wave height

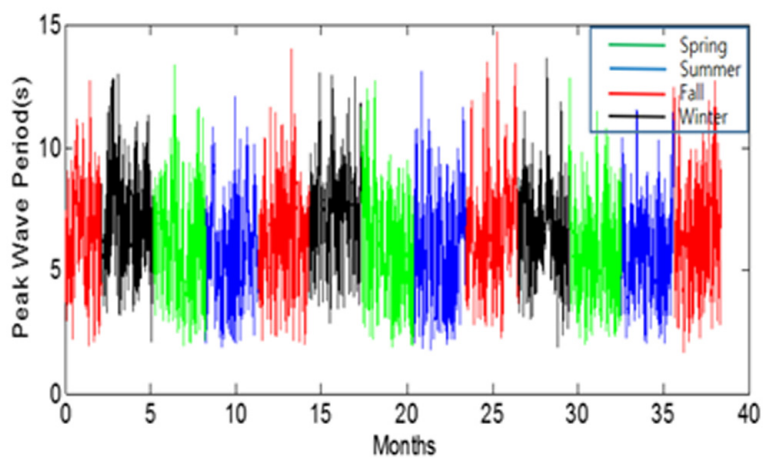

Fig. 7 Temporal variation of period

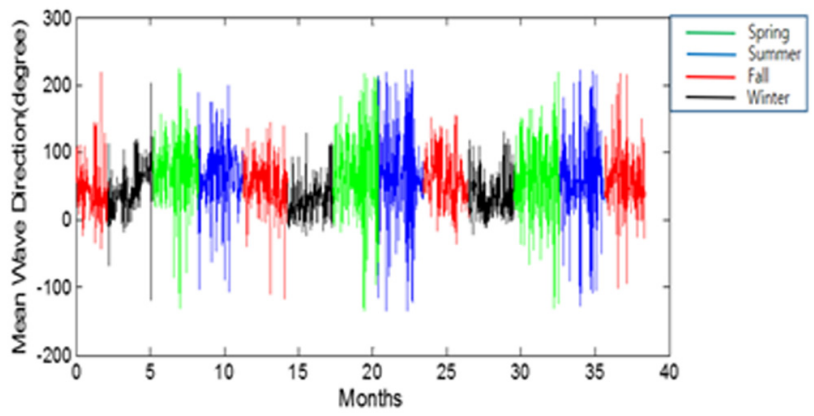

Fig. 8 Temporal variation of wave direction 55,235data에 대한 파고, 주기 및 파향의 시계열 변화가 Figs. 6, 7,8 에 각각 도시되었다. 계절별 특성을 파악하기 쉽도록 봄(Green), 여름(Blue), 가을(Red), 겨울(Black)을 색깔별로 다르게 도시하였다.

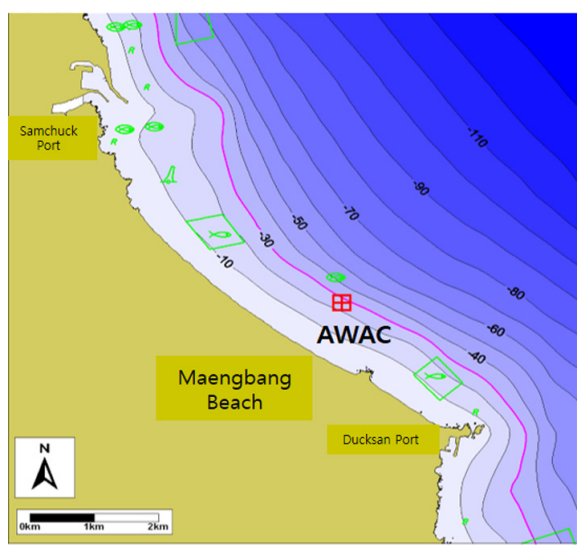

Fig. 5 Location of wave gage (AWAC)
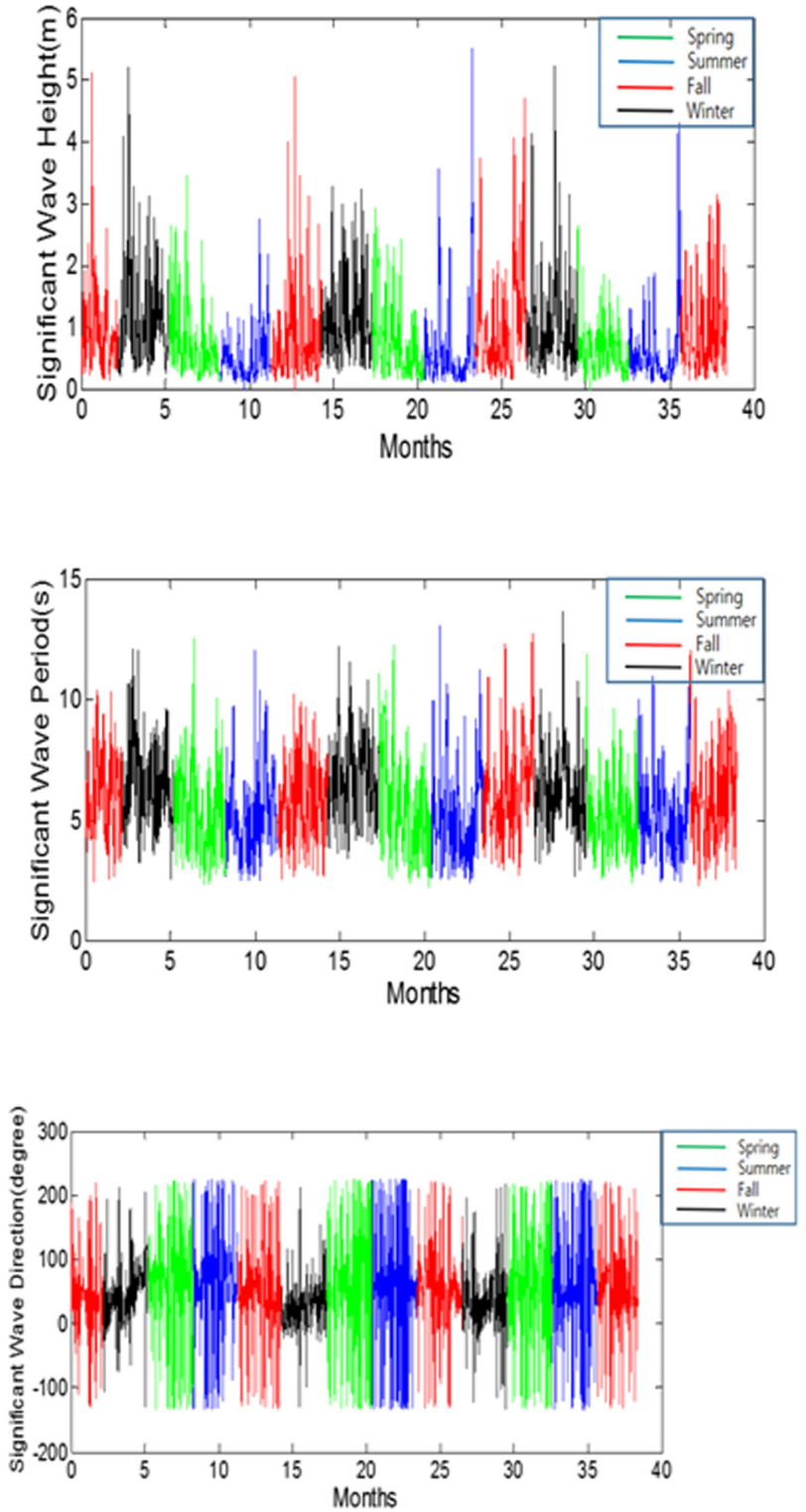


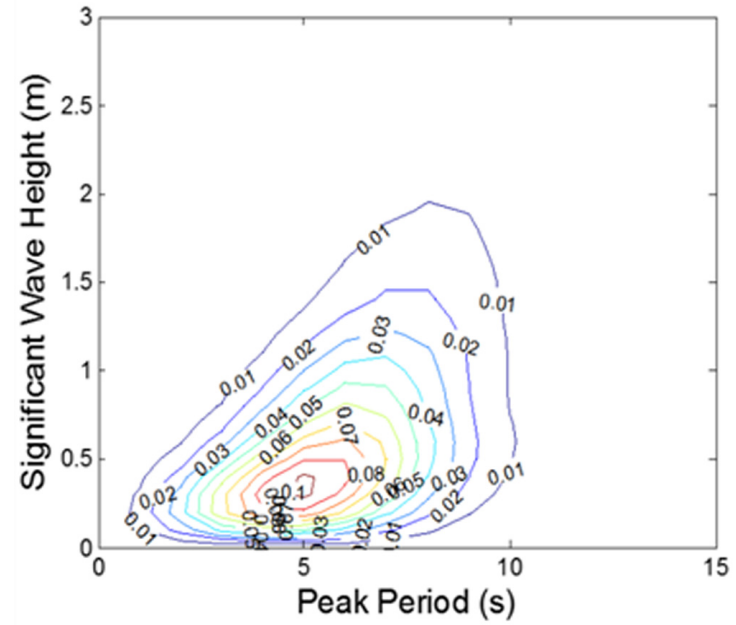

Fig. 9 Joint probability distribution of wave height-wave period

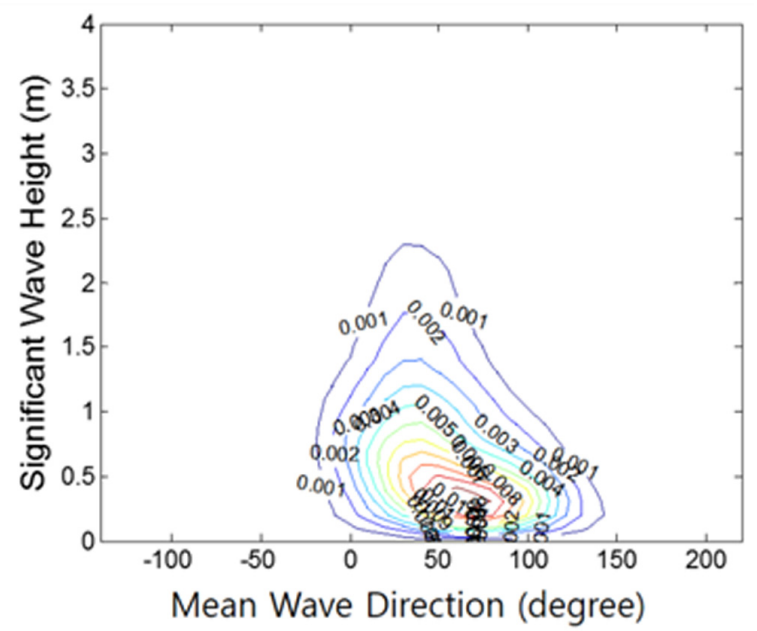

Fig. 10 Joint probability distribution of wave height-wave direction

Figs. 9-10은 파고와 주기 그리고 파고와 파향의 상관성(Correlation) 을 파악하기 위하여 Joint probability를 도시한 것이다. 최고 빈도 입사 파고가 $0.5 \mathrm{~m}$ 보다 작고, 최고 빈도 입사 파향은 $\mathrm{NE}$ 인 것으로 파악되고 있다.

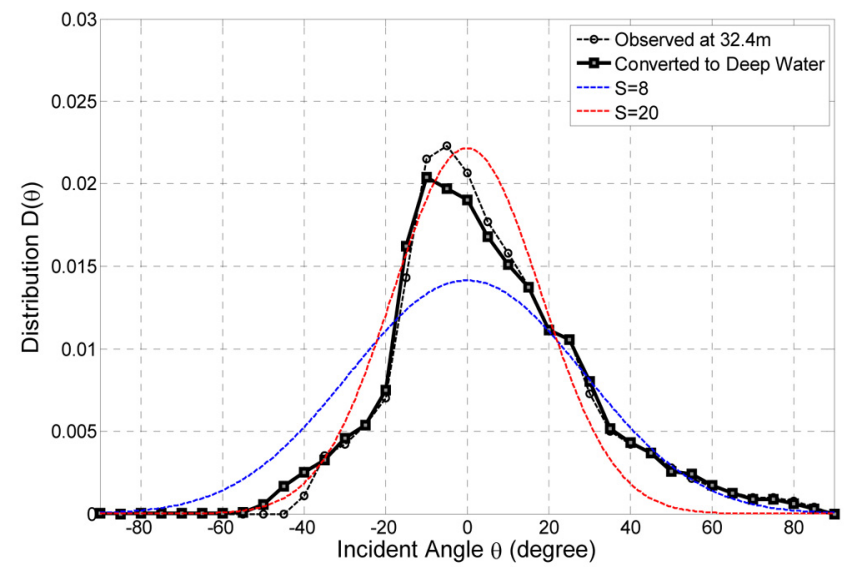

Fig. 11 Wave direction distribution measured at $32.4 \mathrm{~m}$ water depth on Maengbang beach
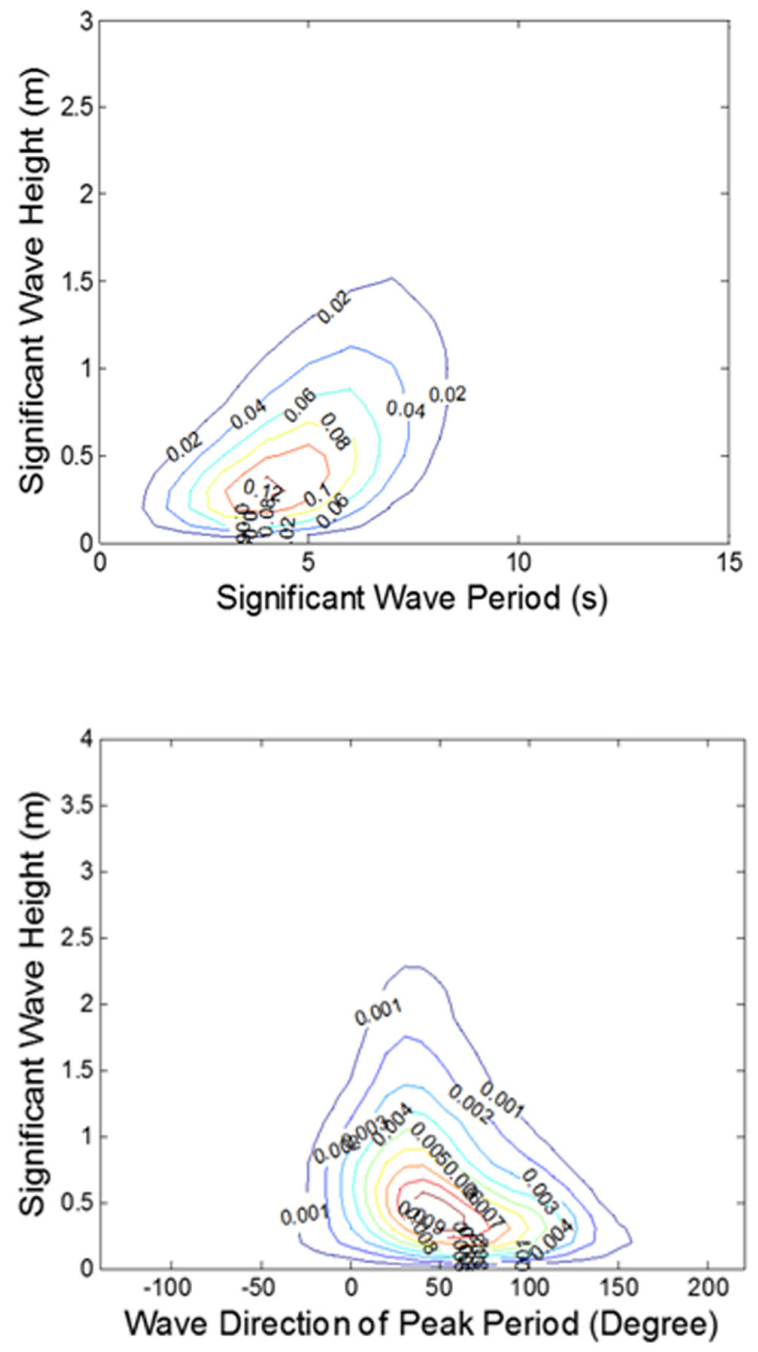

위의 파랑자료를 이용하여 현재 파랑의 주 입사 방향을 기준으로 파랑 스펙트럼의 파향분포도를 도시하면 Fig. 11 과 같다. 이 파향분 포도는 수심 $32.4 \mathrm{~m}$ 에 관측된 파랑 정보이므로 Fig. 5 에 도시된 수심 자료에서처럼 등수심선이 직선적이고 해안선과 거의 평행한 것으 로 간주될 수 있다고 보고 심해에서의 파향분포도를 함께 도시하였 다. 또한 Mitsuyasu and Mizuno(1976)의 파향분포함수와 비교하 여 $\mathrm{E}$ 계열 $\left(0^{\circ} \sim 90^{\circ}\right)$ 은 비교적 분포가 완만하여 $S=8$ 정도인 것으 로 간주되고 $\mathrm{N}$ 계열 $\left(-90^{\circ} \sim 0^{\circ}\right)$ 은 비교적 뾰족하여 $S=20$ 정도인 것 으로 간주된다. Mitsuyasu의 파향분포함수는 $\mathrm{S}$ 의 함수로 아래 식과 같이 주어진다. 단, Fig. 11의 파향분포함수는 연평균 파랑 자료로부터 도시된 것으로 Event성 단기 파랑 자료의 파향분포 함수보다 좀 더 완만한 분포 특성을 보인다.

$$
D(\theta)=\frac{1}{2 \sqrt{\pi}} \frac{\Gamma^{2}(S+1)}{\Gamma(S+1 / 2)} \cos ^{2 s}\left(\frac{\theta}{2}\right)
$$

현재의 해안선 구배에 대한 연안표사량의 분포가 Fig. 12에 도시 되었다. 겨울철 유입되는 파랑 계열은 남쪽으로의 표사이동을 유발 하며 여름철 유입되는 파랑 계열 E Group에 대하여 북쪽으로의 표 


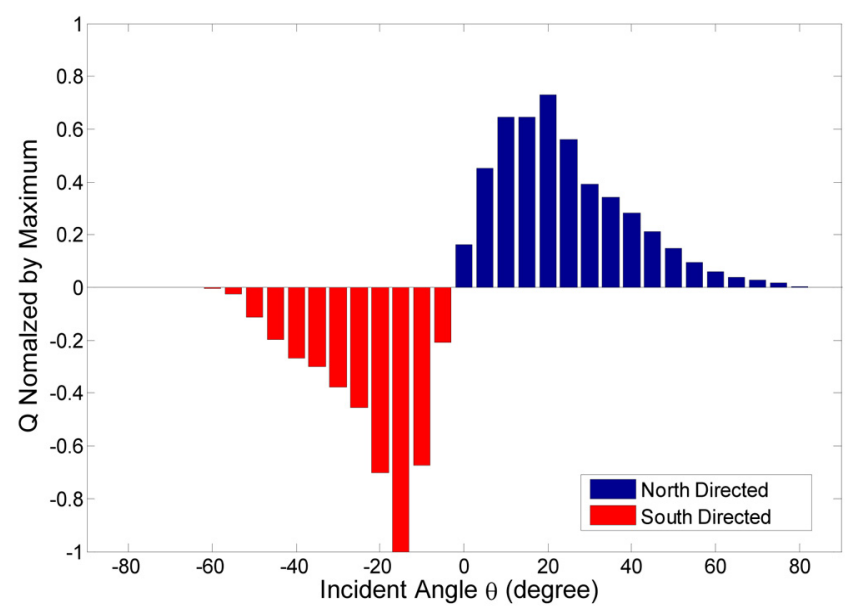

Fig. 12 Distribution of Littoral Drift $Q$ w.r.t. Incident Wave Angle

사이동을 유발하며 현재 해안선의 장기적인 변화가 없다면 북측과 남측 연안표사량의 총량은 균형을 이뤄서 Fig. 12 와 같이 총 연안표 사량은 0 이 되어야 한다. 그러나 구조물이 들어서면 유입 파랑의 차 단이 발생하여 이 연안표사량이 새로운 균형을 이루도록 해안선의 구배가 바뀌며 새로운 평형해안선으로서의 변화가 발생한다.

\section{Hsu et al.(1987)의 평형해안선 경험식 신뢰성 검토}

4.1 연안표사량에 의한 평형해안선과 Hsu et al.(1987)의 평형 해안선 경험식 비교

본 절에서는 파랑 자료로부터 평형해안선을 추정하는 방법론 을 제시하며 또한 Hsu et al.(1987)의 평형해안선 경험식이 얼마 나 타당한지를 살핀다. 평형을 이루는 해안선은 연평균 연안표사 량이 0 이 되는 경우로 가정할 수 있다. 물론 표사계에서 순연안표사 량이 존재하는 특수한 경우는 이에 대한 영향을 보정하는 것이 필 요하지만 본 연구에서는 순연안표사량이 존재하지 않는다고 가정 한다. 따라서 이안제나 방파제 등 구조물이 설치되는 경우 해안으 로의 파랑 유입 환경의 변화로 해안선이 변화하는 데 파랑 환경의 변화로 인하여 발생하는 연간 누적된 연안표사량의 값이 0 이 되는 해안선 기울기를 평형해안선 기울기(Angle of static shoreline gradient)로 가정한다.

Fig. 13는 $\Gamma$ 형 돌제가 무한한 길이의 직선적인 사질 해안에 설치 되는 경우의 우측 해안에서의 해안선 기울기의 변화가 발생하는 경 우이다. $\theta$ 가 $30,60,90,120,150^{\circ}$ 에 대하여 파랑장미도와 연안표사 장미도가 함께 도시되었다. 여기서 파랑장미도의 각 파향성분 $i$ 가 해안선 위치에서 입사파향이 Focus $F$ 를 통해서 입사하는 경우 회절 계수 0.5 를 갖도록 하고 주변 파향 $45^{\circ}$ 폭에서 구조물 배후에서 회절 효과가 반영되도록 아래와 같이 간단한 식에 의하여 회절 영향을 반영하였다. 구조물 배후에서의 수심은 평형에 이르기까지 지속적 으로 변하므로 정확한 회절 영향을 반영하기 쉽지 않으므로 이와 같이 간단하게 처리되었다.

$$
K_{d}\left(\zeta_{i}\right)=\cos ^{2}\left[2\left(\zeta_{i}-\theta-\pi / 8\right)\right] \text { for }-\pi / 8 \leq\left(\zeta_{i}-\theta\right) \leq \pi / 8
$$

전술한 바와 같이 관측된 파랑 정보를 심해 정보로 변환한 후 구

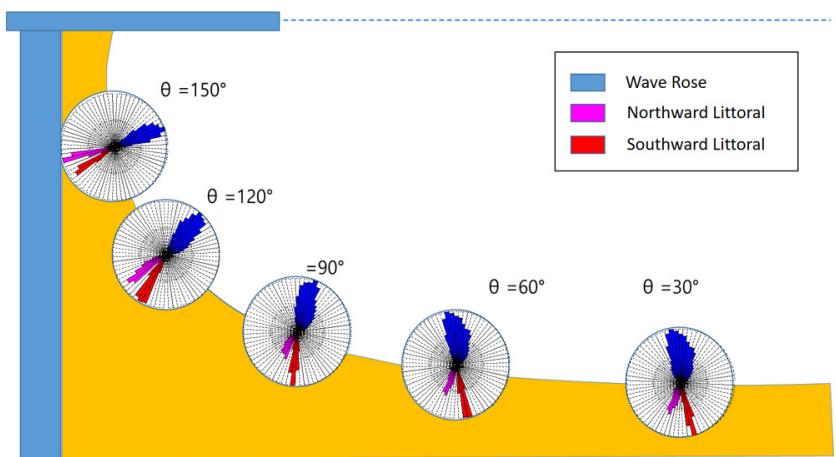

Fig. 13. Wave roses (blue) and littoral drift roses (red) w.r.t $\theta=30$, $60,90,120,150^{\circ}$

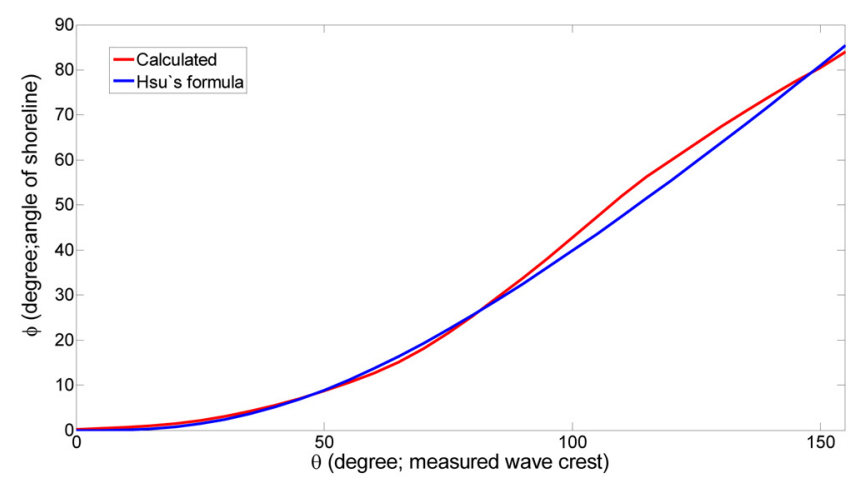

Fig. 14 Comparison of estimated shoreline gradient and shoreline gradient obtained from the Hsu's formula

조물에 의하여 차단 또는 회절이 되는 파랑 효과를 반영하고 식 (10) 의 연안표사량 공식을 이용하여 연안표사량이 0 이 되는 해안선 구 배 $\phi$ 를 $\theta=0^{\circ}$ 부터 $\theta=160^{\circ}$ 까지 계산한 결과가 Fig. 14에 실선으로 도 시되었다. 또한 식 (6)의 $\mathrm{Hsu}$ 의 경험식과 비교한 결과가 함께 파선 으로 도시되었다. 대부분 동해에 위치한 항만 구조물과 같이 Fig. 13 과 같이 $\Gamma$ 형 돌제 구조물이 좌측 편에 놓여있는 관계로 $S=8$ 인 $\mathbf{E}$ 계 열 파랑이 해안선 변화에 영향을 미친 것으로 판단된다.

식 (15)의 적분 기법에 의하여 파랑 자료로부터 얻은 평형해안선 기울기 $\phi$ 는 Fig. 16 과 같이 평형해안선으로 변환될 수 있다.

$$
y=\sum_{i=1}^{N}(\tan \varphi) \times d x
$$

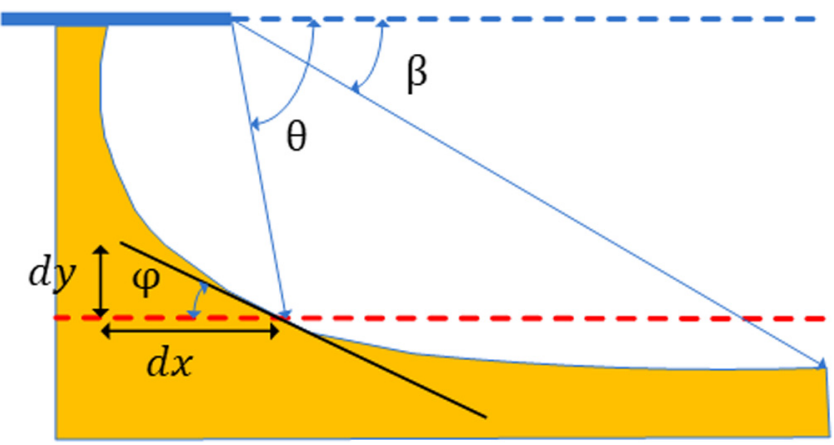

Fig. 15 Definition sketch of estimating the shoreline by integrating shoreline gradients 


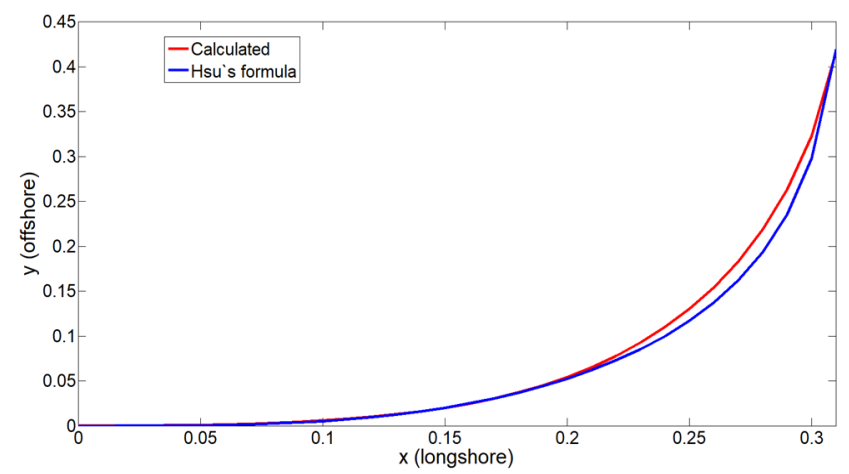

Fig. 16 Comparison of estimated shoreline and empirical shoreline of Hsu et al.(1987)

여기서, $\varphi$ 는 원래의 직선 해안선에 대한 회전각, $y$ 는 원래의 직 선 해안선과 평형해안선의 수직거리 그리고 $x$ 는 기준점에서부 터 평형해안선의 수평거리이다. Fig. 16 은 $\theta$ 의 값에 따른 $\varphi$ 의 값을 추정된 평형해안선과 $\mathrm{Hsu}$ 의 평형해안선을 비교한 것이다.

\section{2. 파향스펙트럼 분포의 민감도 분석}

본 절에서는 파향분포도에 따라 평형 해안선이 어떻게 변하 는 지를 살펴보았다. 식 (13)에서 파향 집중도 계수 $S=5,10,20$, 30 에 대하여 파향 별 파고분포 특성에 따라 동일 구조물이 배 치된 조건에서 추산되는 평형 해안선의 구배 변화와 위치 변화 를 살펴보았다. $S$ 값에 따른 파향 스펙트럼의 분포도가 Fig. 17에 도시되었으며 평형 해안선의 기울기 변화와 위치 변화는 Fig. 18 에 각각 도시되었다. 파향분포함수에 따라 평형해안선이 다소 다른 경향을 보이고 있으며 Mitsuyasu의 분산계수 $S$ 가 3.5일 때 Hsu et al.(1987)의 경험식과 비교하여 전반적으로 잘 일치하는 경 향을 보이고 있지만 $S$ 가 커질수록 해안선 구배는 점점 완만해 지고 구조물 배후에서 해안선 전진 폭이 크게 감소함을 알 수 있었다. $S$ 가 커진다는 것은 Fig. 17에서 알 수 있듯이 파랑에너 지의 파향 분산성이 작고 집중도가 크다는 것을 의미한다.

그러나 연간 파향별 파고스펙트럼의 분포는 Event성 단기 파 랑 자료의 분포와 비교하여 분명히 좀 더 완만한 분포 특성을 보일 것으로 판단되며 이에 대한 좀 더 정밀한 파랑 자료의 조 사 분석이 요구된다. 만약 연간 파향별 심해파고의 스펙트럼이 파향 집중도 계수 $S$ 가 3.5 에서 크게 벗어나지 않아 평형 해안선

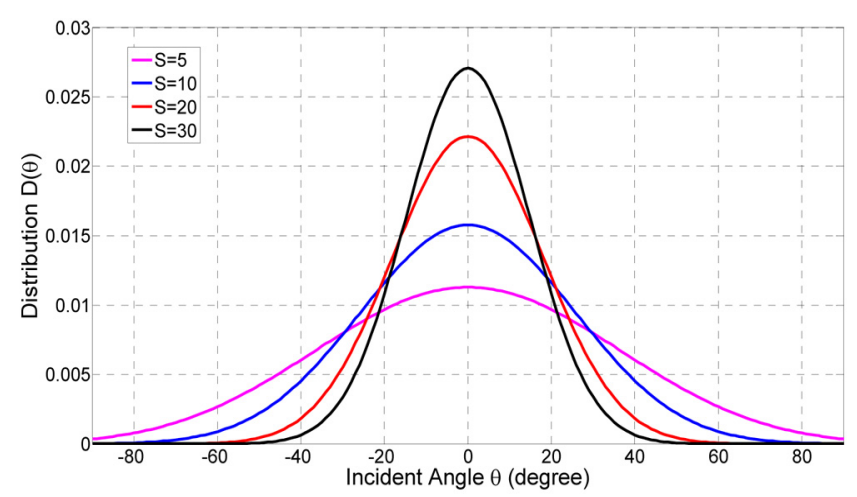

Fig. 17 Wave direction distribution of wave spectrum according to $\mathrm{S}$ value

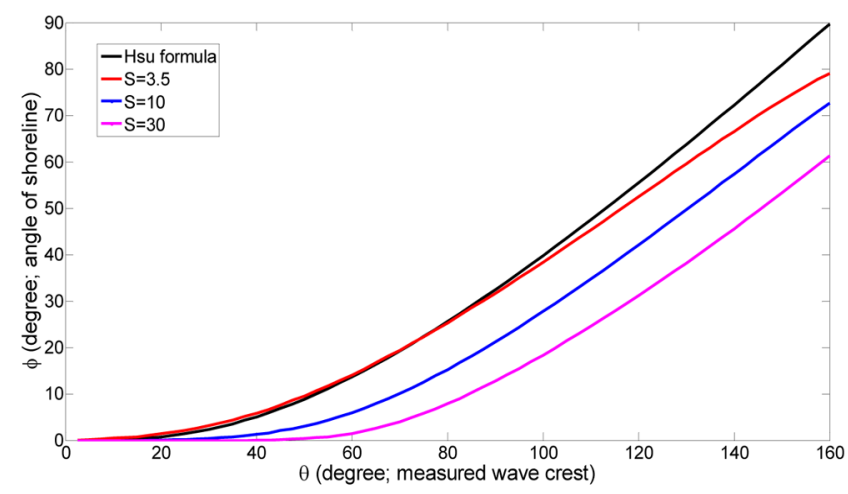

(a)

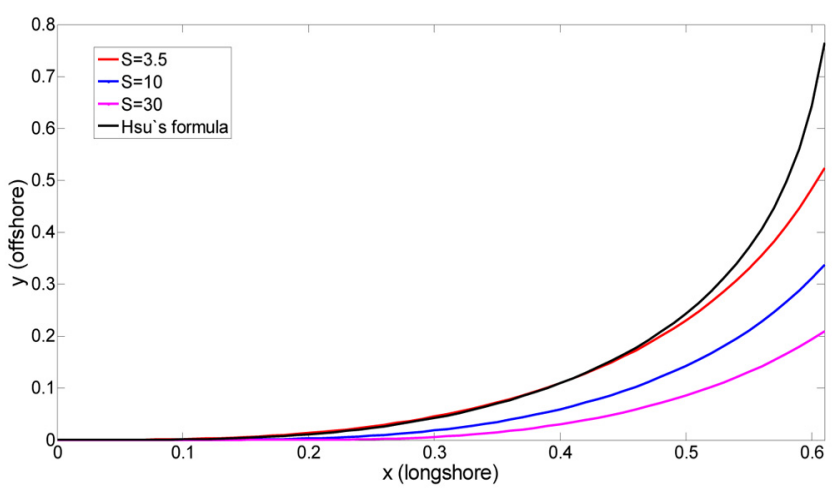

(b)

Fig. 18 Comparison of estimated and Hsu's results in terms of shoreline gradient(a) and shoreline position(b)

의 변화 폭이 작다면 $S$ 에 따른 보정 없이 $\mathrm{Hsu}$ 의 경험식의 직접 활용도가 클 것으로 판단된다.

\section{5. 결 론}

본 연구에서는 우리나라 동해안에서 관측된 파랑 자료로부터 평형해안선을 추정하는 방법론을 제시하며 또한 Hsu et al.(1987) 의 평형해안선 경험식과 비교하여 그 식이 우리나라 해안에 얼마 나 타당한지를 살펴보았다. 관측된 파랑 자료로부터 평형해안선의 구배를 추정하는 방법을 요약하면 다음과 같다. 첫째, 관측된 파랑 정보를 심해 정보로 변환한 후, 둘째 구조물에 의하여 차단 또는 회 절 되는 파랑 효과를 반영하고, 마지막으로 연안표사량 공식을 이용 하여 연안표사량이 0 이 되는 해안선 기울기가 결정된다. 이와 같은 방법을 통하여 동해안 파랑 관측 자료를 이용한 평형해안선과 $\mathrm{Hsu}$ 의 평형해안선 경험식의 비교 - 검토하였으며 해안선의 모양이 비 슷한 추세를 보이고 있음을 확인하였다.

그러나 파향분포함수에 따라 평형해안선이 다소 다른 경향을 보 이며 Mitsuyasu의 분산계수 $S=3.5$ 일 때 $\mathrm{Hsu}$ 의 경험식과 가장 잘 일치하였다. 하지만 $\mathrm{S}$ 가 커질수록 해안선 기울기는 점점 완만해 지며 구조물 배후에서 해안선 전진 폭이 무시하기 어려울 정도 로 감소됨을 알 수 있었다. 따라서 파랑 정보가 없는 경우는 $\mathrm{Hsu}$ 의 경험식을 적용할 수밖에 없지만 만약 입사파랑 정보의 획득이 가능하다면 이의 영향을 분명히 반영할 필요가 있다고 
판단된다. 앞으로 $\mathrm{Hsu}$ 의 경험식을 동해안의 현장 관측된 해안 선 자료와의 비교 및 검토를 통하여 더욱 활용성이 높아질 것 이라 예상된다. 그리고 동해뿐만 아니라 서해와 남해에서도 $\mathrm{Hsu}$ 의 평형해안선 공식의 신뢰성 검토를 통하여 경험식의 타당성을 좀 더 밝힐 수 있을 것이라 예상된다.

$$
\text { 후 기 }
$$

본 연구는 해양수산부의 “연안침식 저감기술 개발” 성과 중 일부이며, (주한국항만기술단의 “침식저감 해안구조물의 배치설 계 연구“ 의 연구비 지원과 공동 논의로 구체적 성과를 이루었 음을 밝히며, 연구비 지원에 감사드립니다. 또한 관측된 파랑 정보를 기꺼이 제공해주신 (주지오시스템리서치 연구진에게도 감사의 말씀드립니다.

\section{References}

Gonzalez, M., Medina, R., Losada M., 2010. On the Design of Beach Nourishment Projects Using Static Equilibrium Concepts: Application to the Spanish Coast. Journal of Coastal Engineering, 57, 227-240.

Hsu, J.R.C., Silvester, R., Xia, Y.M., 1987. New Characteristics of Equilibrium Shaped Bays. Proceedings of 8th Australasian Conference on Coastal and Ocean Engineering, ASCE, 140-144.

Hsu, J.R.C., Evans, C., 1989. Parabolic Bay Shapes and Applications. Proceedings of Institution of Civil Engineers, London, Part 2, 87, 557-570.

Kang, Y.K., Park, H.B., Yoon, H.S., 2010. Shoreline Changes Caused by the Construction of Coastal Erosion Control Structure at the Youngrang Coast in Sockcho, East Korea. Journal of the Korean Society for Marine Environmental Engineering, 13(4), 296-304.

Lee, J.L., Hsu, J.R.C., 2017. Numerical Simulation of Dynamic Shoreline Changes Behind a Detached Breakwater by Using an Equilibrium Formula. Proceedings of ASME 2017 36th International Conference on Ocean, Offshore and Arctic Engineering, OMAE2017-62622, V07AT06A036-V07AT06A036.

Mitsuyasu, H., Mizuno, S., 1976. Directional Spectra of Ocean Surface Waves. Proceedings of Coastal Engineering, 329-348.

Moreno, L.J., Kraus, N.C., 1999. Equilibrium Shape of Headland-bay Beaches for Engineering Design. Proceedings of Coastal Sediments, ASCE, 860-875.

Suh, K.D., Dalrymple, R.A., 1987. Offshore Breakwaters in Laboratory and Field. Journal of Waterway, Port, Coastal and Ocean Engineering. 113(2), 105-121.

Yasso, W.E., 1965. Plan Geometry of Headland-bay Beaches. Journal of Geology, 75(5), 702-714.

\section{Appendix}

Table A1 Hsu and Evans(1989) parabola's coefficients

\begin{tabular}{|c|c|c|c|}
\hline$\beta$ & $C_{0}$ & $C_{1}$ & $C_{2}$ \\
\hline 20 & 0.054 & 1.040 & -0.094 \\
\hline 22 & 0.054 & 1.053 & -0.109 \\
\hline 24 & 0.054 & 1.069 & -0.125 \\
\hline 26 & 0.052 & 1.088 & -0.144 \\
\hline 28 & 0.050 & 1.110 & -0.164 \\
\hline 30 & 0.046 & 1.136 & -0.186 \\
\hline 32 & 0.041 & 1.166 & -0.210 \\
\hline 34 & 0.034 & 1.199 & -0.237 \\
\hline 36 & 0.026 & 1.236 & -0.265 \\
\hline 38 & 0.015 & 1.277 & -0.296 \\
\hline 40 & 0.003 & 1.322 & -0.328 \\
\hline 42 & -0.011 & 1.370 & -0.362 \\
\hline 44 & -0.027 & 1.422 & -0.398 \\
\hline 46 & -0.045 & 1.478 & -0.435 \\
\hline 48 & -0.066 & 1.537 & -0.473 \\
\hline 50 & -0.088 & 1.598 & -0.512 \\
\hline 52 & -0.112 & 1.662 & -0.552 \\
\hline 54 & -0.138 & 1.729 & -0.592 \\
\hline 56 & -0.166 & 1.797 & -0.632 \\
\hline 58 & -0.196 & 1.866 & -0.671 \\
\hline 60 & -0.227 & 1.936 & -0.710 \\
\hline 62 & -0.260 & 2.006 & -0.746 \\
\hline 64 & -0.295 & 2.076 & -0.781 \\
\hline 66 & -0.331 & 2.145 & -0.813 \\
\hline 68 & -0.368 & 2.212 & -0.842 \\
\hline 70 & -0.405 & 2.276 & -0.867 \\
\hline 72 & -0.444 & 2.336 & -0.888 \\
\hline 74 & -0.483 & 2.393 & -0.903 \\
\hline 76 & -0.522 & 2.444 & -0.912 \\
\hline 78 & -0.561 & 2.489 & -0.915 \\
\hline 80 & -0.600 & 2.526 & -0.910 \\
\hline
\end{tabular}

Table A2 Comparison of calculated shoreline of the East Sea and empirical formulas of Hsu et al., (1987)

\begin{tabular}{ccc}
\hline \hline$\theta$ & calculated shoreline & Hsu's shoreline \\
\hline 0 & -0.2 & 0 \\
5 & -0.4 & 0 \\
10 & -0.6 & -0.1 \\
15 & -1 & -0.3 \\
20 & -1.4 & -0.8 \\
25 & -2.1 & -1.4 \\
30 & -3.1 & -2.4 \\
35 & -4.2 & -3.6 \\
40 & -5.5 & -5.1 \\
45 & -7 & -6.9 \\
50 & -8.7 & -8.9 \\
55 & -10.6 & -11.2 \\
60 & -12.7 & -13.7 \\
65 & -15.1 & -16.4 \\
70 & -18.1 & -19.3 \\
75 & -21.6 & -22.4 \\
80 & -25.4 & -25.6 \\
85 & -29.5 & -29 \\
90 & -33.7 & -32.5 \\
95 & -38.1 & -36.1 \\
100 & -42.7 & -39.8 \\
105 & -47.4 & -43.6 \\
110 & -52 & -47.5 \\
115 & -56.3 & -51.5 \\
120 & -60 & -55.5 \\
125 & -63.7 & -59.6 \\
130 & -67.4 & -63.8 \\
135 & -70.9 & -68 \\
140 & -74.2 & -72.3 \\
145 & -77.4 & -76.6 \\
150 & -80.5 & -80.9 \\
155 & -83.9 & -85.3 \\
160 & -88.3 & -89.7 \\
\hline & &
\end{tabular}

